\title{
Transformasi Bidang Litbang Menjadi Badan Riset dan Inovasi Daerah Provinsi Bali
}

\author{
I Made Agus Gelgel Wirasuta \\ Kelompok Ahli Pembangunan Provinsi Bali (2018-2023) \\ Program Studi Farmasi, FMIPA, Universitas Udayana \\ email: gelgel.wirasuta@unud.ac.id
}

\begin{abstract}
Bung Karno/Sukarno (the first president of Indonesia) placed research as the main ingredient in planning the Pola Pembangunan Semesta Berencana and used the research results on an ongoing basis to realize the ideals of national development, namely: "Welfare with social justice for all Indonesian people (Kesejahteraan yang berkeadilan sosial bagi seluruh masyarakat Indonesia)", and increase the nation's competitiveness. The Law No. 11 of 2019 concerning the National System of Science and Technology requires the role of local governments in the development of research, inventions, and innovations, as well as utilizing the results in the form of Intellectual Property. The transformation of the Regional Research and Development Institute is a must to carry out the mandate of the Law No. 11 of 2019. This study conveys the transformation of Bali's Regional R\&D Agency (Litbangda) towards badan Riset dan Inovasi Daerah Provinsi (Regional Research and Innovation Agency of Bali Province).
\end{abstract}

Keywords: research, innovation, research and development, Bali Province.

\section{LATAR BELAKANG}

Bung Karno dalam surat tertulis pada tanggal 28 Agustus 1959 serta pidatonya tanggal 17 Agustus 1959 tentang pembangunan semesta berencana "overall plan" adalah pembangunan yang tidak berdiri sendiri, tidak terlepas hubungannya dengan bidang-bidang lain yaitu kehidupan negara dan masyarakat. Dalam melaksanakan pembangunan semesta, perlu adanya perencanaan overall, suatu perencanaan semesta yang didasarkan pada kebutuhan dan kepribadian rakyat Indonesia, tanpa mengabaikan contoh pengalaman-pengalaman dalam pembangunan di luar negeri dengan perpaduan pengalaman dan keadaan yang konkrit di dalam negeri. Tujuan pola pembangunan semesta berencana adalah membentuk susunan masyarakat Indonesia baru, yang menjamin terlaksananya masyarakat yang adil dan makmur berdasarkan Pancasila. Oleh Bung Karno, salah satu tujuan pembangunan negara ialah memajukan negara dari yang sebagian kehidupannya masih dikuasai oleh imperialisme dan feodalisme, ke Negara yang merdeka penuh.

Negara dalam tujuan mencapai tujuannya untuk melindungi segenap bangsa Indonesia dan seluruh tumpah darah Indonesia, memajukan kesejahteraan umum, mencerdaskan kehidupan bangsa dan ikut melaksanakan ketertiban duniam negara berkewajiban memajukan ilmu pengetahuan dan teknologi dengan menjungjung tinggi nilai agama dan persatun bangsa untuk kemajuan peradaban serta kesejahteraan umum, maka diterbitkan UU nomor 11 tahun 2019 tentang Sistem Nasional IImu Pengetahuan dan Teknologi. Sistem Nasional IImu Pengetahuan dan Teknologi digunakan sebagai landasan dalam perumusan kebijakan pembangunan agar mampu meperkuat daya dukung ilmu pengetahuan dan teknologi dalam rangka mencapai tujuan negara, serta meningkatkan daya saing dan kemandirian bangsa. 
Sistem nasional ilmu pengetahuan dan teknologi adalah pola hubungan yang membentuk kerkaitan secara terencana, terarah, dan terukur, serta berkelanjutan antar unsur kelembagaan dan sumber daya sehingga terbagun suatu jejaring ilmu pengetahuan dan teknologi sebagai satu kesatuan utuh dalam dukungan penyelenggaraan ilmu pengetahuan dan teknologi sebagai landasan ilmiah dalam perumusan dan penetapan kebijakan nasional. Sistem ini mengatur keterlibatan semua pihak, seperti pemerintah pusat dan daerah, dunia usaha dan masyarakat terlibat dalam satu jaringan pengembangan ilmu pengetahuan dan teknologi. Dalam setiap pasalnya selalu menempatkan pemerintah pusat dan daerah dalam satu kesatuan. Beberapa terminologi yang dijelaskan dalam ketentuan umum pada UU ini adalah: ilmu pengetahuan, teknologi, penyelengaraan Iptek, pendidikan, penelitian/riset, pengembangan, pengkajian, penerapan, perekayasa, invensi, inventor, inovasi, difusi Iptek, alih teknologi, audit teknologi, kliring teknologi, kekayaan intelektual, kelembagaan Iptek, sumber daya iptek, badan usaha, pemangku kepentingan pemerintah pusat dan daerah.

Mengacu pada Peraturan Menteri Dalam Negeri RI no 86 tahun 2017, menyatakan Visi-Misi Kepala Daerah terpilih merupakan janji Calon Kepala Derah dan harus dituangkan ke dalam Rancangan Pembangunan Daerah Jangka Menengang (RPJMD) dan Rancangan Pembangunan Daerah Jangka Panjang (RPJMP). Visi-Misi tersebut sudah tertuang dalam Pola Pembangunan Semesta Berencana Daerah Bali tahun 2018-2023. Bung Karno menyatakan riset adalah menjadi pondasi dasar dalam penyusunan rencana pembangunan semesta berencana dan kajian kebijakan pembangunan seharusnya dilakukan oleh Lembaga penelitian. Hasil kajian tersebut semestinya menjadi dasar masukan dalam perencanaan pembangunan selanjutnya secara berkelanjutan.

Undang-undang no 11 tahun 2019 tentang Sistem Nasional IImu Pengetahuan dan Teknologi menempatkan peran dan kewajiban pemerintah daerah melaksanakan riset, invensi, inovasi dan pemanfaatan hasil-hasilnya dalam bentuk kekayaan intelektual dalam pembangunan daerahnya guna meningkatkan daya saing daerah dan meningkatkan kesejahteraan masyarakatnya.

Ketentuan tersebut di atas mengamanahkan suatu transformasi peran Lembaga. Kajian dan studi ini menampilkan tranformasi Lembaga penelitian dan pengembangan daerah Provinsi Bali menuju Badan Riset dan Inovasi Daerah Bali.

\section{Pola Pembangunan Semesta Berencana Bali 2018-2023}

Pola Pembangunan Semesta Berencana Bali 2018-2023 untuk mengantarkan Bali menuju Era Baru. Suatu Era yang ditandai dengan tatanan kehidupan baru yaitu Bali yang Kawista, Bali kang tata-titi tentram kerta raharja, gemah ripah lohjinawi. Bali era baru adalah tatanan kehidupan holistik yang meliputi tiga dimensi utama.

Dimensi pertama, bisa menjaga/memelihara keseimbangan sekala-niskala Alam, Krama (manusia), dan Kebudayaan Bali (genuine Bali). Dimensi pertama memiliki tiga aspek yaitu alam, krama dan kebudayaan.

Aspek alam Bali dijaga secara niskala dan sakala. Secara niskala melalui pemeliharaan dan pelestarian keagungan, kesucian, dan taksu alam Bali, yang meliputi tempat-tempat suci, laut, danau, sungai, sumber mata air lain, gunung, hutan, tumbuhtumbuhan (pertanian dan perkebunan), dan lingkungan alam secara niskala dengan 
melaksanakan upakara dan upacara Pakertih Yadnya secara periodik, yaitu: Atma Kertih, Segara Kertih, Wana Kertih, Danu Kertih, Jana Kertih dan Jagat Kertih. Secara sakala dilakukan upaya pemeliharaan dan pelestarian alam Bali melalui regulasi, kebijakan, dan program untuk konservasi alam, perlindungan tempat-tempat suci, laut, danau, sungai, sumber mata air lain, gunung, hutan, tumbuh-tumbuhan (pertanian dan perkebunan), dan lingkungan alam sehingga alam Bali menjadi hijau, indah, dan bersih. Memelihara alam Bali secara niskala dan sakala bertujuan untuk menjadikan Bali sebagai Padma Bhuwana, yaitu sebagai pusat atau muaranya dunia dan sebagai pusat peradaban dunia.

Aspek krama Bali (masyarakat Bali) terdiri dari mengembangkan tata kehidupan krama Bali berdasarkan nilai-nilai filsafat Sad Kertih baik secara sakala maupun niskala: Atma Kertih, Danu Kertih, Wana Kertih, Segara Kertih , Jana Kertih, dan Jagat Kertih dan mengembangkan jatidiri, integritas, dan kualitas Krama Bali sesuai dengan nilai-nilai adat istiadat, agama, tradisi, seni, dan budaya, serta kearifan lokal masyarakat Bali. Unsur pengembangan jatidiri Krama Bali membangun jatidiri yang memiliki rasa syukur, bahagia, dan bangga dilahirkan sebagai orang Bali. Usur pengembangan integritas krama Bali meliputi pembangunan karakter positif, etika, moralitas, kejujuran, disiplin, ketekunan/keuletan, dan kecintaan dalam setiap aktvitas kehidupan. Usur pengembangan kualitas Krama Bali dalam bentuk kompetensi, profesional, kreatif, inovatif, dan memiliki daya saing dengan semangat pantang menyerah.

Aspek kebudayaan Bali terdiri dari: a) memajukan Kebudayaan Bali dari hulu sampai ke hilir yang meliputi: adat istiadat, agama, tradisi, seni, dan budaya, serta kearifan lokal Bali melalui upaya pelindungan, pembinaan, pengembangan, dan pemanfaatan obyek pemajuan kebudayaan; b) menjadikan Kebudayaan Bali sebagai hulu pembangunan Bali yang menjiwai segala aspek pembangunan Bali; mengarusutamakan budaya dalam berbagai aspek pembangunan Bali; dan c) menjadikan kebudayaan Bali sebagai basis dan pilar utama pembangunan perekonomian masyarakat Bali.

Dimensi kedua yaitu terpenuhinya kebutuhan, harapan, dan aspirasi Krama Bali dalam berbagai aspek kehidupan. Kebutuhan esesnsi krama Bali, yang menjadi prioritas adalah: a) kebutuhan dasar, seperti: pangan, sandang, papan, air, listrik, kesehatan, dan pendidikan dalam jumlah dan kualitas yang memadai; b) jaminan sosial dan perlindungan tenaga kerja; c) kebutuhan pelayanan dalam pelaksanaan kehidupan adat, agama, tradisi, seni, dan budaya bagi Krama Bali: sarana-prasarana, transportasi, dan infrastruktur dalam jumlah dan kualitas yang memadai; d) pendapatan per kapita, dan tersedianya lapangan kerja sesuai dengan kebutuhan bagi Krama Bali; dan e) rasa aman dan nyaman kehidupan Krama Bali.

Dimensi ketiga adalah memiliki kesiapan yang cukup (suatu manajemen resiko) dalam mengantisipasi/menghadapi munculnya permasalahan dan tantangan baru, dalam tataran lokal, nasional, dan global yang akan berdampak secara positif maupun negatif terhadap kondisi di masa yang akan datang. Peningkatan kesiapan managemen resiko krama Bali dalam menghadapi tantangan kehidupan dicapai melalui: a) penguatan dan pelembagaan adat, agama, tradisi, seni, dan budaya agar tetap kokoh; b) pengarusutamaan sumber daya lokal Bali dalam berbagai aspek kehidupan, terutama dalam pengembangan dan pengelolaan perekonomian; $c$ ) 
peningkatan daya saing Krama Bali; d) membangkitkan kembali rasa jengah sebagai orang Bali dan rasa tindih terhadap Bali; dan e) memperkuat rasa kebersamaan, budaya gotong royong, dan sikap-sikap kolektif Krama Bali.

Pilar tiga dimensi di atas bertujuan untuk mewujudkan kehidupan Krama Bali dan Gumi Bali sesuai dengan Prinsip Trisakti Bung Karno: berdaulat secara politik, berdikari secara ekonomi, dan berkepribadian dalam kebudayaan. Arah pembangunan Bali Era Baru terbingkai dalam visi, misi, dan program pembangunan Bali tahun 20182023. Pola Pembangunan Semesta Berencana Bali 2018-2023 dituangkan dalam program prioritas dan program pendukung yang mencakup hulu sampai hilir.

Visi pembangunan Bali tahun 2018-2023 yaitu nangun sat kerthi loka Bali mewujudkan Bali Era Baru melalui pola pembangunan semesta berencana. Yang mengandung makna; "Menjaga Kesucian dan Keharmonisan Alam Bali Beserta Isinya, Untuk Mewujudkan Kehidupan Krama Bali Yang Sejahtera dan Bahagia, SakalaNiskala Menuju Kehidupan Krama dan Gumi Bali Sesuai Dengan Prinsip Trisakti Bung Karno: Berdaulat secara Politik, Berdikari Secara Ekonomi, dan Berkepribadian dalam Kebudayaan Melalui Pembangunan Secara Terpola, Menyeluruh, Terencana, Terarah, dan Terintegrasi Dalam Bingkai Negara Kesatuan Republik Indonesia Berdasarkan Nilai-Nilai Pancasila 1 Juni 1945."

Mewujudkan visi pembangunan Bali 2018-2023 ditempuh melalui 22 misi pembangunan Bali yang menjadi arah kebijakan pembangunan Bali sebagai Pola Pembangunan Semesta Berencana. Misi tersebut antara lain:

1. Memastikan terpenuhinya kebutuhan pangan, sandang, dan papan dalam jumlah dan kualitas yang memadai bagi kehidupan Krama Bali.

2. Mewujudkan kemandirian pangan, meningkatkan nilai tambah dan daya saing pertanian, dan meningkatkan kesejahteraan petani.

3. Mengembangkan pelayanan kesehatan masyarakat yang terjangkau, merata, adil dan berkualitas serta didukung dengan pengembangan sistem dan data base riwayat kesehatan Krama Bali berbasis kecamatan.

4. Memastikan tersedianya pelayanan pendidikan yang terjangkau, merata, adil, dan berkualitas serta melaksanakan wajib belajar 12 tahun.

5. Mengembangkan sistem pendidikan dasar dan pendidikan menengah berbasis keagamaan Hindu dalam bentuk Pasraman di Desa Pakraman/Desa Adat.

6. Mengembangkan sumber daya manusia yang berdaya saing tinggi yaitu berkualitas dan berintegritas: bermutu, profesional dan bermoral serta memiliki jati diri yang kokoh yang dikembangkan berdasarkan nilai-nilai kearifan lokal Krama Bali.

7. Mengembangkan sistem jaminan sosial secara konprehensif dan terintegrasi bagi kehidupan Krama Bali sejak mulai kelahiran, tumbuh dan berkembang sampai akhir masa kehidupannya.

8. Menghasilkan tenaga kerja yang kompeten, produktif, berkualitas dan memiliki daya saing tinggi serta memperluas akses kesempatan kerja di dalam dan di luar negeri.

9. Mengembangkan sistem jaminan sosial dan perlindungan tenaga kerja yang komperhensif, mudah dijangkau, bermutu, dan terintegrasi bagi Krama Bali yang bekerja di dalam dan di luar negeri. 
10. Memajukan kebudayaan Bali melalui peningkatan pelindungan, pembinaan, pengembangan dan pemanfaatan nilai-nilai adat, agama, tradisi, seni, dan budaya Krama Bali.

11. Mengembangkan tata kehidupan Krama Bali secara sakala dan niskala berdasarkan nilai-nilai filsafat Sad Kertih yaitu Atma Kertih, Danu Kertih, Wana Kertih, Segara Kertih, Jana Kertih, dan Jagat Kertih.

12. Memperkuat kedudukan, tugas dan fungsi Desa Pakraman/ Desa Adat dalam menyelengarakan kehidupan krama Bali yang meliputi Parahyangan, Pawongan, dan Palemahan

13. Mengembangkan destinasi dan produk pariwisata baru berbasis budaya dan berpihak kepada rakyat yang terintegrasi antar kabupaten/kota se-Bali.

14. Meningkatkan promosi pariwisata Bali di dalam dan di luar negeri secara bersinergi antar kabupaten/kota se-Bali dengan mengembangkan inovasi dan kreatifitas baru.

15. Meningkatkan standar kualitas pelayanan kepariwisataan secara konprehensif.

16. Membangun dan mengembangkan pusat-pusat perekonomian baru sesuai dengan potensi kabupaten/kota di Bali dengan memberdayakan sumber daya lokal untuk mendukung pertumbuhan ekonomi dalam arti luas.

17. Membangun dan mengembangkan industri kecil dan menengah berbasis budaya (branding Bali) untuk memperkuat perekonomian Krama Bali.

18. Meningkatkan pembangunan infrastruktur (darat, laut dan udara) secara terintegrasi serta konektivitas antar wilayah untuk mendukung pembangunan perekonomian serta akses dan mutu pelayanan publik di Bali.

19. Mengembangkan sistem keamanan terpadu yang ditopang dengan sumber daya manusia serta sarana prasarana yang memadai untuk menjaga keamanan daerah dan Krama Bali serta keamanan para wisatawan.

20. Mewujudkan kehidupan Krama Bali yang demokratis dan berkeadilan dengan memperkuat budaya hukum, budaya politik dan kesetaraan gender dengan memperhatikan nilai-nilai budaya Bali.

21. Mengembangkan tata kehidupan Krama Bali, menata wilayah, dan lingkungan yang hijau, indah, dan bersih.

22. Mengembangkan sistem tata kelola pemerintahan daerah yang efektif efisien, terbuka, transparan, akuntabel dan bersih serta meningkatkan pelayan publik terpadu yang cepat, pasti dan murah.

Pelaksanaan pembangunan semesta berencana dituangkan ke dalam dua kelompok yaitu program prioritas dan program pendukung, yang mencangkup hulu sampai hilir. Program prioritas mencakup lima bidang prioritas yaitu: 1) Bidang pangan, sandang dan papan; 2) Bidang kesehatan dan Pendidikan; 3) Bidang jaminan social dan ketenagaan; 4) Bidang Adat, Agama, Tradisi, Seni dan Budaya; dan 5) Bidang Pariwisata. Program pendukung meliputi: 1) Pembangunan infrastruktur pendukung bidang pangan, papan, pendidikan, adat, agama, dan kebudayaan; 2) Pembangunan instrastruktur darat, laut, dan udara secara terintegrasi dan koneksitivitas; 3) Pembangunan perekonomian Bali; 4) Pembangunan keamanan Bali; dan 5) Program legislasi.

Paradigma pembangunan Bali 2018-2023 adalah pelaksanaan pola pembangunan semesnta berencana yang berlangsung secara sistematis, masif, dan 
dinamis dalam tataran lokal, nasional, dan global. Pembangunan yang dimaksud adalah pembangunan yang ditandai dengan: 1) bisa menjaga/memelihara Genuine Bali; 2) bisa memenuhi kebutuhan, harapan, dan aspirasi Krama Bali dalam berbagai aspek kehidupan; dan 3) memiliki kesiapan yang cukup dalam mengantisipasi/menghadapi munculnya permasalahan dan tantangan baru yang akan berdampak secara positif maupun negatif terhadap kondisi di masa yang akan datang untuk menuju Era Baru. Bali Era Baru adalah suatu Era yang ditandai dengan tatanan kehidupan baru Krama Bali yaitu nangun sat kerthi loka Bali. Pendekatan pembangunan menuju Bali era baru melalui pendekatan berbagai aspek:

1) Pembangunan Bali harus dilakukan secara holistik; membangun seluruh wilayah Bali secara terpola, terencana, terarah, dan terintegrasi yang memastikan adanya keseimbangan, pemerataan, dan keadilan pembangunan antar wilayah Kabupaten/Kota Se-Bali.

2) Pemerintah Provinsi Bali harus membangun Kabupaten/Kota Se-Bali, bukan membangun di Kabupaten/ Kota Se-Bali secara parsial dengan tujuan, sasaran, dan obyek yang berbeda antara Provinsi dengan Kabupaten/Kota. Artinya, sektor-sektor yang dibangun oleh Pemerintah Provinsi harus sesuai dengan sektor-sektor yang dibangun oleh Pemerintah Kabupaten/Kota Se-Bali baik menyangkut tujuan, sasaran, dan obyek serta lokasi pembangunan.

3) Untuk itu, proses perencanaan pembangunan dalam berbagai sektor harus dilakukan secara bersama-sama oleh Pemerintah Provinsi dan Pemerintah Kabupaten/Kota Se-Bali sehingga dapat ditentukan pola pembangunan yang dipakai dan skema penganggarannya; yang bersumber dari APBN, APBD Provinsi, dan APBD Kabupaten/Kota Se-Bali. Dengan pendekatan demikian maka pembangunan Bali akan menjadi lebih efektif dan efisien serta tepat sasaran.

4) Dalam konteks kepentingan membangun Kabupaten/Kota Se-Bali, yaPembangunanng wilayah kewenangannya berada di Pemerintah Kabupaten/Kota sebagaimana diatur dalam peraturan perundang-undangan, maka Pemerintah Provinsi harus lebih banyak berperan sebagai koordinator, regulator, dan fasilitator; bukan sebagai operator langsung, sehingga proses perencanaan dan pelaksanaan pembangunan bisa dilaksanakan secara bersama-sama dan bersinergi dengan para pihak yang berorientasi pada efektivitas efisiensi, dan tepat sasaran serta mengedepankan kepentingan Bali secara keseluruhan. Sementara pembangunan Bali yang menjadi wilayah kewenangan Pemerintah Provinsi sebagaimana diatur dalam peraturan perundang-undangan harus dilakukan secara terintegrasi dan bersinergi antara Pemerintah Provinsi dengan Pemerintah Kabupaten/Kota, mengingat lokus pembangunan tersebut berada di wilayah Kabupaten/Kota.

5) Sejalan dengan kepentingan tersebut, Gubernur Bali sebagai Kepala Pemerintahan di daerah dan perwakilan Pemerintah Pusat di daerah harus menerapkan kepemimpinan yang lebih mengedepankan pendekatan budaya, bukan mengedepankan kepemimpinan formalistik yang bersifat hirarki dan struktural dalam memimpin pembangunan Bali yang di dalamnya terdapat Bupati/Walikota yang memiliki kewenangan sebagaimana diatur dalam peraturan perundang-undangan dalam membangun daerahnya.

6) Dengan pendekatan kepemimpinan Gubernur Bali secara demikian maka Bali yang wilayahnya sangat kecil dan memiliki sumber daya sangat terbatas, pembangunan 
Bali dapat dilakukan melalui pendekatan pembangunan Bali dalam satu kesatuan wilayah, satu perencanaan, dan satu manajemen dengan satu kepemimpinan Gubernur Bali.

7) Ke-depan dalam menghadapi dinamika pembangunan Bali dalam berbagai sektor khususnya yang berkaitan dengan pembangunan kepariwisataan dengan adanya tantangan pada tataran lokal, nasional, dan global maka diperlukan kepemimpinan yang lurus, lascarya, prinsipil, berani, dan tegas dalam bersikap mengambil posisi terutama terkait penegakkan peraturan perundang-undangan, kepemimpinan yang berani bersikap nindihin Gumi Bali, guna menjaga dan memelihara Genuine Bali; termasuk kepemimpinan yang berani melakukan terobosan kebijakan baru terhadap segala upaya untuk memajukan Bali.

\section{Peran Badan Litbang Daerah dalam Pembangunan Daerah}

Undang-Undang no 18 tahun 2002 tentang Sistem Nasional Penelitian, Pengembangan, dan Penerapan IImu Pengetahuan dan Teknologi mengamanahkan pemerintah daerah membentuk Badan Litbang Daerah. Pasal 8 menyatakan Badan Litbang adalah lembaga berdiri sendiri, sedangkan pasal 14 pemerintah daerah dapat membangun kawasan Iptek yang bertujuan untuk menumbuh kembangkan budaya Iptek di masyarakat. Pasal 20 menehaskan fungsi dari Pemerintah Daerah dalam menumbuhkembangkan motivasi, memberikan stimulasi dan fasilitas, serta menciptakan iklim yang kondusif bagi pertumbuhan, serta sinergi unsur kelembagaan, sumberdaya, dan jaringan Iptek di wilayah pemerintahannya sebagai bagian yang tidak terpisahkan dari Sistem Nasional Penelitian, Pengembangan dan Penerapan Iptek. Dalam mengemban amanah tersebut Pemerintah daerah dalam pasal 21 UU ini menegaskan Pemerintah Daerah perlu membentuk Lembaga Litbang sebagai unit kerja pemerintah daerah. Amanat ini mengisyaratkan Balitbang Daerah untuk mengemban tugas dan fungsi pengembangan ilmu pengetahuan dan teknologi, pendayagunaan Iptek dan pemanfaatan hasil-hasil litbang tersebut secara aktif.

Litbang daerah dalam UU no 18 tahun 2002 bertugas mengorganisasikan pembentukan SDM, penelitian, pengembangan, perekayasaan, novasi dan difusi teknologi. Dalam melakukan pengembangan inovasi daerah Litbang daerah bertangung jawab dalam mencari berbagai invesi dalam pengembangan inovasi berbasis potensi daerah, sehingga pada akhirnya mampu meningkatkan daya saing daerah. Litbang daerah dalam mengemban tugas ini diharapkan mampu bekerjasama dengan lebaga peneitian yang ada di Perguruan Tinggi atau lembaga penelitian vertikal/nasional baik yang berlokasi di daerahnya atau bukan.

UU no 23 tahun 2014 tentang Pemerintahan daerah menyatakan penelitian dan pengembangan merupakan kewenangan pemerintah daerah. Pada pasal 386 , UU ini menyebutkan, pemerintah daerah dapat melakukan inovasi dalam menyelenggaraan pemerintahan daerah. Adapun prinsip inovasi tersebut adalah: peningkatan efisiensi, perbaikan efektivitas, perbaikan kualitas pelayanan, tidak ada konflik kepentingan, berorientasi kepada kepentingan umum, dilakukan secara terbuka, memenuhi nilai-nilai kepatuhan, dan dapat dipertanggungjawabkan hasilnya tidak untuk kepentingan diri sendiri. Peraturan Pemerintah no. 38 tahun 2017 tentang inovasi daerah menjelaskan, bahwa semua bentuk pembaharuan dalam penyelengaraan pemerintahan daerah merupakan inovasi daerah. Tujuan invovasi daerah adalah meningkatkan kinerja 
penyelenggaraan pemerintahan daerah, sehingga tercapai sasaran inovasi, yaitu: peningkatan pelayanan publik, pemberdayaan dan peran serta masyarakat, serta peningkatan daya saing daerah.

Tugas Balitbang daerah ditegaskan dalam PerMen DagRi no. 5 tahun 2017 tentang Pedoman Nomenklatur Perangkat Daerah Provinsi dan Daerah Kabupaten/Kota Yang Melaksanakan Fungsi Penunjang Penyelenggaraan Urusan Pemerintahan, adalah melaksanakan penelitian dan pengembangan di bidang penyelenggaraan urusan pemerintahan. Adapun fungsi Balitbangda adalah: a) menyusun kebijakan teknis penelitian dan pengembangan; b) menyusun perencanaan program dan anggaran penelitian dan pengembangan; c) melaksanakan penelitian dan pengembangan; d) melaksanakan pengkajian kebijakan lingkup urusan pemerintahan daerah; e) memfasilitasi dan melaksanakan inovasi daerah; f) memantau, mengevaluasi dan melaporkan atas pelaksanaan penelitian dan pengembangan di daerah; g) mengoordinasikan dan mengsinkronisasikan pelaksanaan penelitian dan pengembangan lingkup pemerintahan daerah; h) melaksanakan administrasi penelitian dan pengembangan daerah; dan i) pelaksanaan tugas lain yang diberikan oleh Pimpinan Daerah.

Tugas pemerintah daerah dalam mengembangkan invensi dan inovasi tertuang dalam pasal 34 UU no 11 tahun 2019 tentang Sistem Nasional IImu Pengetahuan dan Teknologi. Pemerintah daerah wajib memfasilitasi pemanfaatan, adopsi, inkubasi, kemitraan, penguatan kawasan IImu Pengetahuan dan Teknologi sesuai dengan kesiapan dan keunggulan daerah, promosi, dan penggunaan hasil invensi dan inovasi dalam program pembangunan secara berkelanjutan, termasuk melakukan pembagian peran dengan Badan Usaha. Invensi dan inovasi ditujukan untuk: a) menjadi solusi permasalahan nasional, b) memadukan sudut pandang dan/atau konteks teknis, fungsional, bisnis, sosial budaya, dan estetika, dan c) menghasilkan nilai tambah dari produk dan/atau proses produksi bagi kesejahteraan masyarakat. Invensi dan inovasi dihasilkan dari: a) penelitian dasar, penelitian terapan, dan pengembangan, b) alih teknologi, c) rekayasa balik, d) intermediasi teknologi, e) difusi Iptek, dan/atau f) komersialisasi teknologi.

Pasal 33 UU no 11 tahun 2019 mewajibkan pemerintah daerah bersinergi dalam memfasilitasi pengembangan inkubasi Teknologi, kemitraan industri, dan/atau pengembangan kawasan IImu Pengetahuan dan Teknologi sesuai dengan kesiapan dan keunggulan daerah. Sedangkan Pasal 36, mewajibkan pemerintah daerah menggunakan hasil invensi dan inovasi nasional. Pasal 22 menjelaskan kepemilikan kekayaan Intelektual hasil dari invensi dan inovasi yang didanai oleh pemerintah daerah. Pemerintah daerah berperan serta dalam pendanaan sistem nasional Iptek (dicatumkan dalam pasal 25, 61, dan pasal 68).

Pemerintah daerah diwajibkan melakukan pembinaan dalam penyelenggaraan Iptek di wilayahnya melalui penumbuhkembangan motivasi, pemberian stimulasi dan fasilitasi, serta penciptaan iklim yang kondusif bagi pertumbuhan serta sinergi unsur kelembagaan, sumber daya, dan jaringan Iptek sebagai bagian yang tidak terpisahkan dari Sistem Nasional Ilmu Pengetahuan dan Teknologi.

Tugas dan fungsi badan Litbang daerah sesuai Permendagri no. 5 tahun 2017 tidak lagi sesuai dengan tuntutan UU no.11 tahun 2019, sehingga diperlukan revormasi Litbang daerah. 


\section{Transformasi Litbang Daerah Bali}

Peraturan Gubernur Bali no. 67 tahun 2018 tentang Kedudukan, Susunan Organisasi, Tugas dan Fungsi, Serta Tata Kerja Badan Perencanaan Pembangunan Daerah, Penelitian dan Pengembangan menjelaskan LitBang adalah merupakan Bidang penelitian dan pengembangan di bawah Badan perendanaan pembangunan daerah Bali. Tuntutan tugas dan fungsi pemerintah daerah dalam sistem nasional Iptek menuntut peningkatan peran organisasi LitBang Daerah Bali.

Peraturan Daerah Nomor 7 Tahun 2019 tentang Perubahan atas Peraturan Daerah Nomor 10 Tahun 2016 tentang Pembentukan dan Susunan Perangkat Daerah memisahkan bidang penelitian dan pengembangan dari Badan Perencanaan Pembangunan Daerah menjadi tersendiri yaitu Badan Riset dan Inovasi Daerah Bali. Kedudukan, Susunan Organisasi, Tugas dan Fungsi, Serta Tata Kerja Badan Riset Dan Inovasi Daerah Bali ditetapkan dalam Peraturan Gubernur Bali. Badan dipimpin oleh Kepala Badan yang berkedudukan di bawah dan bertanggung jawab kepada Gubernur melalui Sekretaris Daerah. Susunan organisasi Badan Riset dan Inovasi Daerah Bali ditampilkan dalam gambar 1.

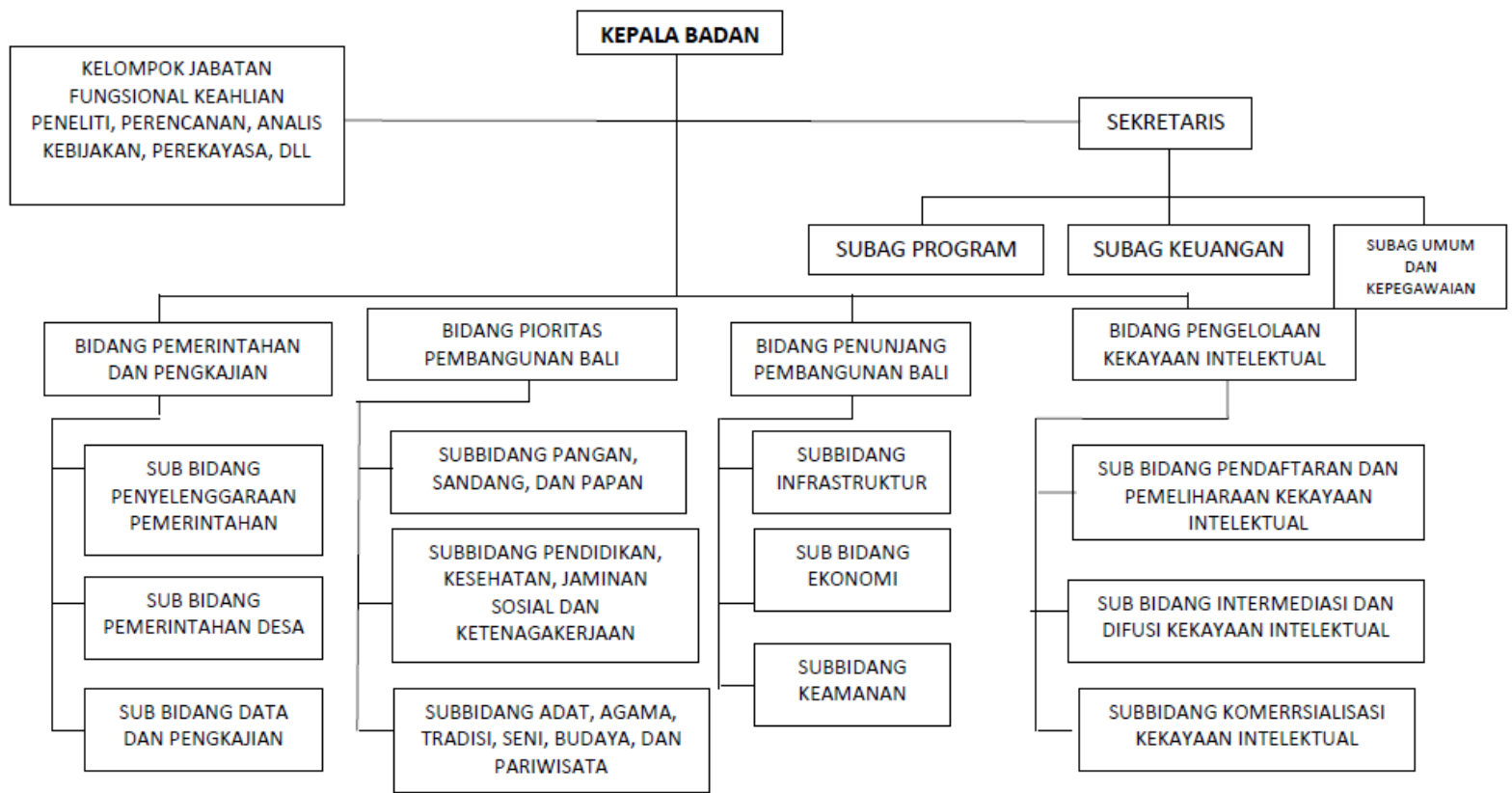

Gambar 1. Susunan Organisasi Badan Riset dan Inovasi Daerah Bali.

Badan mempunyai tugas melaksanakan Riset dan Inovasi, serta pengelolaan kekayaan intelektual Pemerintah Provinsi yang mendukung tercapainya pembangunan Provinsi, tertuang dalam Rencana Pembangunan Jangka Menengah Daerah Semesta Berencana Provinsi sehingga bermanfaat dalam meningkatkan kesejahteraan dan daya saing Krama Bali secara sakala dan niskala sesuai dengan ketentuan Peraturan Perundang-undangan. Adapun fungsi dari Badan Riset dan Inovasi Daerah Bali adalah: 
a. penyusunan kebijakan Riset dan Inovasi Pemerintah Provinsi;

b. menyusun perencanaan program dan anggaran Riset dan Inovasi Daerah Pemerintah Provinsi;

c. melaksanakan Riset dan Inovasi Daerah Pemerintah Provinsi;

d. melaksanakan kerjasama dan bersinergi dengan perguruan tinggi, lembaga penelitian dan pengkajian, dunia usaha dan industri, beserta pihak lain yang terkait dalam melaksanakan Riset dan Inovasi Daerah Pemerintah Provinsi;

e. melaksanaan pengkajian kebijakan lingkup urusan Pemerintah Provinsi;

f. pemantauan, evaluasi dan pelaporan atas pelaksanaan Riset dan Inovasi Daerah Pemerintah Provinsi;

g. melakukan koordinasi, sinkronisasi, dan integrasi pelaksanaan Riset dan Inovasi Daerah Pemerintah Provinsi;

h. melaksanakan administrasi Riset dan Inovasi Daerah;

i. mengembangkan sistem dan klaster Inovasi Derah; dan

j. melaksanakan tugas lain yang diberikan oleh Gubernur.

Aspek-aspek bidang pemerintahan dan pengkajian peraturan yang menjadi fokus tugas adalah penyelenggaraan otonomi daerah, pemerintah umum, kelembagaan, ketatalaksanaan, keuangan dan asset daerah, reformasi birokrasi, ketertiban dan ketentraman umum dan perlindungan masyarakat. Aspek-aspek khusus pada penyelenggaraan pemerintahan Desa Dinas dan Desa Adat meliputi penataan kelembagaan, ketatalaksanaan, aparatur, keuangan dan aset, dan badan usaha milik desa. Bidang ini jua bertugas fasilitasi pemberian rekomendasi penelitian bagi warga negara asing untuk diterbitkannya izin penelitian oleh instansi yang berwenang.

Aspek-aspek bidang prioritas pembangunan daerah yang menjadi fokus tugas adalah pada: a) subbidang pangan, sandang dan papan, meliputi aspek-aspek jumlah dan kualitas yang memadai, peningkatan nilai tambah dan daya saing, dan orientasi eksport; b) subbidang pendidikan, kesehatan jaminan sosial dan ketenagakerjaan meliputi aspek-aspek akses dan kualitas layanan pendidikan, jaminan sosial dan ketenagakerjaan yang komprehensif dan terintegrasi dalam mewujudkan manusia unggul, pengembangan system dan database pelayanan kesehatan, pengembangan system pendidikan, jaminan sosial, dan ketenagakerjaan berbasis kearifan lokal Bali dan keagamaan Hindu, dan c) subbidang adat, agama, tradisi, seni, budaya, dan pariwisata meliputi aspek-aspek pemajuan kebudayaan Bali, pengembangan tata kehidupan krama Bali secara sakala dan niskala berdasarkan nilai-nilai filsafat Sad Kerthi, serta penguatan kedudukan, tugas dan fungsi Desa Adat, pengembangan destinasi dan produk pariwisata baru berbasis budaya yang berpihak kepada rakyat dan terintegrasi, peningkatan promosi pariwisata Bali dengan pengembangan inovasi dan krativitas, dan pengembangan standar kualitas kepariwisataan secara komprehensif.

Aspek-aspek bidang penunjang pembangunan daerah yang menjadi fokus tugas adalah pada a) subbidang infrastruktur meliputi aspek-aspek peningkatan pembangunan infrastruktur (darat, laut dan udara) secara terintegrasi serta konektivitas antar wilayah untuk mendukung pembangunan perekonomian serta akses dan mutu pelayanan publik di Bali; b) subbidang ekonomi meliputi aspek-aspek pengembangan pusat-pusat perekonomian baru sesuai dengan potensi kabupaten/kota di Bali, 
pemberdayaan sumber daya lokal untuk mendukung pertumbuhan ekonomi dalam arti luas, pengembangan industri kecil dan menengah berbasis budaya (branding Bali) untuk memperkuat perekonomian Krama Bali, penanaman modal, koperasi, usaha kecil dan menengah perindustrian, perdagangan, dan Badan Usaha Milik Daerah, dan c) subbidang keamanan meliputi aspek-aspek sistem Jaga Baya berbasis Tri Hita Karana dalam mewujudkan kondisi keamanan Bali yang mayoritas beragama hindu dan berkebudayaan tinggi, sebagai destinasi wisata dunia, serta bagian dari Negara Kesatuan Republik Indonesia, sehingga sistem keamanan Jaga Baya berbasis kearifan lokal terintegrasi dengan sistem kemanan nasional yang berstandar internasional.

Tugas pada bidang pengelolaan kekayaan intelektual adalah mengelola semua potensi kekayaan intelektual Pemerintah Provinsi untuk meningkatkan kesejaheraan krama Bali dan meningkatkan daya saing daerah Bali. Aspek-aspek tugas meliputi: a) pendaftaran potensi kekayaan intelektual dan pemeliharaan kekayaan intelektual yang telah didaftarkan, b) mengintermediasi kekayaan intelektual hasil inensi dan inovasi Pemerintah Provinsi melalui mengimplementasikan teknologi kepada calon pengguna dan mengidentifikasi kebutuhan calon pengguna terhadap teknologi yang dibutuhkan, inkubasi teknologi, temu bisnis teknologi, kemitraan dan, atau promosi, c) mendifusikan pengetahuan dan teknologi kekayaan intelektual hasil invensi dan inovasi Pemerintah Provinsi melalui peningkatan kapasitas pengetahuan dan teknologi, evaluasi kesiapan pengguna teknologi, dan pembinaan peningkatan kapasitas daya serap pengguna teknologi, dan d) kormersialisasi kekayaan intelektual hasil invensi dan inovasi Pemerintah Provinsi Bali melalui inkubasi teknologi, kemitraan usaha/industri, dan atau pengembangan kawasan pengetahuan dan teknologi dengan mempertimbangkan aspek-aspek adat, agama, tradisi, seni dan budaya sebagai dasar nangut sat kerthi loka Bali.

\section{KESIMPULAN}

Transformasi Litbangda provinsi Bali ditujukan untuk mengawal tercapainya tujuan Pembangunan Semesta Berencana Provisi Bali 2018-2023, serta memusatkan pelaksanaan riset, invesi, inovasi di Provinsi Bali. BaRi Bali mengkoordinasikan pelaksanaan riset dan inovasi dengan bekerjasama dengan semua pengampu kempentigan dan pada akhirnya memanfaatkan hasil riset dan inovasi guna menigkatkan kesejahteraan krama Bali, serta meningkatkan daya saing Bali di level nasional, regional dan internasional.

\section{DAFTAR PUSTAKA}

Ketetapan MPRS No. II/MPRS/1960 tentang Garis-Garis Besar Pola Pembangunan Nasional Semesta Berencana Tahapan Pertama 1961-1969.

Ketetapan MPRSRI No.I/MPRS/1960 tentang Manisfesto Politik RI Sebagai Garis-garis Besar Daripada Haluan Negar.,

Peraturan Daerah Provinsi Bali Nomor 10 Tahun 2016 tentang Pembentukan dan Susunan Perangkat Daerah (Lembaran Daerah Tahun 2016 Nomor 10, Tambahan Lembaran Daerah Nomor 8) sebagaimana telah diubah dengan Peraturan Daerah Nomor 7 Tahun 2019 tentang Perubahan Atas Peraturan Daerah Nomor 10 Tahun 2016 tentang Pembentukan dan Susunan Perangkat 
Daerah (Lembaran Daerah Provinsi Tahun 2019 Nomor 7, Tambahan Lembaran Daerah Provinsi Bali Nomor)

Peraturan Menteri Dalam Negeri Nomor 5 Tahun 2017 tentang Pedoman Nomenklatur Perangkat Daerah Provinsi dan Daerah Kabupaten/Kota Yang Melaksanakan Fungsi Penunjang Penyelenggaraan Urusan Pemerintahan (Berita Negara Republik Indonesia Tahun 2017 Nomor 197)

Peraturan Menteri Dalam Negeri Republik Indonesia Nomor 17 Tahun 2016 tentang Pedoman Penelitian dan Pengembangan di Kementerian Dalam Negeri dan Pemerintahan Daerah

Peraturan Pemerintah Nomor 18 Tahun 2016 tentang Perangkat Daerah (Lembaran Negara Republik Indonesia Tahun 2016 Nomor 114, Tambahan Lembaran Negara Republik Indonesia Nomor 5887)

Undang-Undang Nomor 12 Tahun 2011 tentang Pembentukan Peraturan Perundangundangan (Lembaran Negara Republik Indonesia Tahun 2011 Nomor 82, Tambahan Lembaran Negara Republik Indonesia Nomor 5234

Undang-Undang Nomor 5 Tahun 2014 tentang Aparatur Sipil Negara (Lembaran Negara Republik Indonesia Tahun 2014 Nomor 6, Tambahan Lembaran Negara Republik Indonesia 5494)

Undang-Undang Nomor 11 tahun 2019 tentang Sistem Nasional Ilmu Pengetahuan dan Teknologi, Lembaran Negara no 6374

Undang-Undang Nomor 23 Tahun 2014 tentang Pemerintahan Daerah (Lembaran Negara Republik Indonesia Tahun 2014 Nomor 244, Tambahan Lembaran Negara Republik Indonesia 5587) sebagaimana telah diubah beberapa kali, terakhir dengan Undang-undang Nomor 9 Tahun 2015 tentang Perubahan Kedua Atas Undang-Undang Nomor 23 Tahun 2014 tentang Pemerintahan Daerah (Lembaran Negara Republik Indonesia Tahun 2015 Nomor 58, Tambahan Lembaran Negara Republik Indonesia Nomor 5657). 